International Journal of Applied Linguistics \& English Literature

ISSN 2200-3592 (Print), ISSN 2200-3452 (Online)

Vol. 1 No. 5; September 2012 [Special Issue on General Linguistics]

\title{
Evaluation of English Language Teaching Departments of Turkish and Iranian Universities in Terms of Politeness Strategies with Reference to Request
}

\author{
Maryam Rafieyan, MA \\ Islamic Azad University, Tabriz Branch, Iran \\ Email: Rafieyan_Maryam@yahoo.com \\ Tel: 00989143117926
}

Received: 31-07- 2012

Accepted: 30-08- 2012

Published: 03-09- 2012

doi:10.7575/ijalel.v.1n.5p.226

URL: http://dx.doi.org/10.7575/ijalel.v.1n.5p.226

\begin{abstract}
The ultimate objective in post-method pedagogy is developing language learner's communicative competence to enable them to participate in communication acts. Effective oral communication entails observation of a number of conversational principles and appropriate use of various strategies to avoid violation of mutually recognized rules, e.g. politeness strategies. Some researchers believe that politeness strategies have a number of universal Features (Goff man, 1967, 1971: Goody, 1978 a). In line with previous research studies, the present study set out to investigate whether nationality would influence the use of request politeness strategies by Iranian and Turkish EFL learners at the same proficiency level. Participants in this study included 448 students at four different levels of proficiency who were majoring in English language teaching at Gazi University in turkey and Islamic Azad University - Tabriz Branch. 224 Turkish students at four different grade levels and the same number of Iranian students participated directly in this phase of the research. Each grade level group consisted of 56 students. The researcher administered a questionnaire enquiring their preferences in selecting the proper forms of requests ( Blum - Kulka \& Olshtain , 1985). The statistical analysis revealed a strong correlation in intra-groups while the inter - group results displayed relatively significant differences . The Turkish participants used request politeness strategies more appropriately than Iranians which support the role of culture in the use of such strategies. The findings highlight the necessity of observing cultural background in teaching communication strategies such as request politeness strategies particularly in EFL contexts.
\end{abstract}

Keywords: Politeness Strategies, Request, Cross-Cultural analysis, Communication Strategies, Cultural Background

\section{Introduction}

Conversation analysis and the use of different strategies to convey intended meaning through various modes are issues that have occupied the minds of so many scholars and miscellaneous researches have been done so far.

Austin (1962) and Searle (1965, 1981), for example, classified speech acts in different types and for each type set a special rule. Grice (1964) proposed that conversations conform to four maxims and named them as Quantity, Quality, Relevance, and Manner.

Lakoff (1973) reduced Grice's maxims to two and named them as: Be clear and Be polite. In her view, these two are sufficient rules to guarantee "pragmatic competence". Based on this classification, Lakoff concentrates on the rules of politeness of which there are three:

1. Don't impose on your addressee.

2. Let the addressee make his own decisions.

3. Make the addressee feel good, be friendly.

Brown and Levinson (1978) define politeness as maintaining H's face, that is, being imposed on and approved of in certain respects. Face refers to wants, and Brown and Levinson (1978) argue that we have two types of wants: ego-preserving wants and public-self preserving wants, which refer to people's desire to be considered 
International Journal of Applied Linguistics \& English Literature

ISSN 2200-3592 (Print), ISSN 2200-3452 (Online)

Vol. 1 No. 5; September 2012 [Special Issue on General Linguistics]

contributing members of the society. The former generates negative face, and the latter, positive face. Making a request more polite decreases the imposition involved and helps maintain the relationship between $\mathrm{S}$ (speaker) and $\mathrm{H}$ (hearer). However, that increases the chance of rejection, and $\mathrm{S}$ does not achieve the action goal. Thus, it is important to increase H's approval of S.

Politeness is a communication strategy that people use to maintain and develop relationships (relation goal). Because requests are essentially discourteous, achieving a request (action goal) may damage the relationship between the people concerned (Leech, 1983). Politeness, therefore, is an important issue in making requests.

Brown and Levinson (1978) present five super strategies of politeness that show different levels of politeness.

1) A speaker may perform the request "baldly", making no attempt to acknowledge the hearer's face wants.

2) A speaker may perform the request while attending to the hearer's positive face wants using what Brown and Levinson (1978: 106) label a positive politeness strategy.

3) A speaker might perform the request with negative politeness, acknowledging the hearer's negative face wants, the desire to be unimpeded and not imposed on.

4) A speaker may "go off-record" in performing the request. Here, the speaker performs the act but in a vague manner

5) (e.g . , hinting) that could be interpreted by the hearer as some other act.

6) A speaker may not make the request and therefore not gain the goal.

The first strategy in the list is not polite at all, and the last one is very polite, but does not gain anything .T thus there are four different levels of politeness strategies that have potential to gain the goal.

\subsection{Politeness}

Speaking and having communication with others is an activity which takes place when people involved. The mutual cooperation of interlocutors through recognition of certain conventions controls the way of interpretation and their use of language, and hence each interlocutor is responsible for the way of using language appropriately and should be held responsible for any violation of mutually recognized conventions.

The ways we address someone directly and the manner in which refer to the same person are not always the same. The use of direct address formulae is governed by a relationship between two participants the speaker and the hearer. When choosing a term of reference, however, the speaker not only has to take into account his/her relationship with the hearer but also has to decide how to present the referent in a situationally appropriate manner (Nevala, 2004: 2125-26).

Leech (1983: 80) referring to politeness principles tries to imply that cooperative principle in itself cannot explain "(i) why people are often so indirect in conveying what they mean; and (ii) what is the relation between sense and force when non-declarative types of sentence are being considered." Therefore, he suggests, a complementary principle, as he named politeness principle, is needed to complement it. Based on Leech (1983) the politeness principle has two formulations, one as being negative and the other positive. The negative one "minimizes the expression of impolite beliefs' while the positive one "maximizes the expression of polite beliefs" (p. 80).

Based on this assumption, he observes politeness as a gradable entity that indicates the more polite utterance is the one with indirectness of its force. The reason behind it is the increase in respondent choice but decrease in utterance's force. Leech points out that societies are different in using different maxims and the weight they attach to them.

Lakoff (2001: 212) advocating an approach based on discourse analysis states that to have a clear understanding of what is considered 'polite', one should have insights into the way that language is used in a particular sociocultural setting without which the complexity of the politeness and what should be considered polite remains unsolved.

Through concentration on a particular speech act located in a specific cultural and societal time and space place, we can come to understand a great deal about who we are, what we want, and the rules and assumptions that bind us together as a society [Lakoff (2001: 212) cited in Daly (2004: 446)]. Referring to the above mentioned assumptions, one can claim that the term politeness cannot be defined or clarified without neglecting cooperative behavior which can be explained in terms of mutual presentation of 'face'. 
International Journal of Applied Linguistics \& English Literature

ISSN 2200-3592 (Print), ISSN 2200-3452 (Online)

Vol. 1 No. 5; September 2012 [Special Issue on General Linguistics]

\subsection{Face}

Brown and Levinson (1987: 59- 60) argue that face is something that every member of a society has. It can be defined as one's public self-image. Goffman (1967: 5) defines the concept of face as "the positive self-value a person effectively claims for himself." Thomas (1995: 164) defines it as "every individual's feeling of self-worth or self-image."

In all these definitions, face is considered as a quality that can be enhanced, maintained or lost; that is to say, everyone's face depends on everyone else's being maintained. (Brown and Levinson 1987: 61). Hence, every time a speaker wants to utter something he needs to be careful that his utterance will either maintain or threaten the addressee's face in a way that he intends to do, and at the same time enhancing or maintaining his own face.

"It is in general in every participant's best interest to maintain each other's face. That is to act in ways that assure the other participants that the agent is heedful of the assumptions concerning face" Brown and Levinson (1987: $61)$.

The assumptions that Brown and Levinson (1987: 61) refer to are termed as positive and negative face.

\subsection{Negative Face and Negative Politeness}

Fukada (2004: 1992) defines negative face as "the claim to one's territory, personal preserves, and rights to nondistraction, such as freedom of action and freedom from imposition.” Brown and Levinson (1987: 62) define negative face as:

The want of every 'competent adult member' that his actions be unimpeded by others. Negative politeness "is oriented mainly toward partially satisfying (redressing) H's negative face, his basic want to maintain claims of territory and self-determination.

Brown and Levinson (1987: 70) believe that "negative politeness is primarily 'avoidance-based' and realization of its strategies requires that the speaker recognizes and honors the addressee's negative face wants and tries not to interfere with addressee's freedom of action." Hence, negative politeness is characterized by self-effacement, formality and restraint, with attention to very restricted aspects of H's self-image, centering on his want to be unimpeded (p. 70).

\subsection{Positive Face and Positive Politeness}

Fukada (2004: 1992) defines it in a rather similar way as Daly where he refers to it as "the desire to be appreciated or approved of by other members of a society." Brown and Levinson (1987: 62) define positive face as "the want of every member that his wants be desirable to at least some others."

Positive politeness by definition is "redress directed to the addressee's positive face, his perennial desire that his wants (or the actions/ acquisitions/ values resulting from them) should be thought of as desirable." (Brow and Levinson, 1987: 101)

As Brown \& Levinson (1987: 103) put it, positive politeness utterances are used to extend intimacy, to imply common grounds or shared wants even between strangers who assume that they share similarities for the purpose of interaction.

\subsection{Off-record politeness}

Another way of expressing politeness is using off-record communicative act to provide a variety of defensible interpretations. "A communicative act is the off- record if it is done in such a way that it is not possible to attribute only one clear communicative intention to the act" (Brown and Levinson, 1987: 211). Off record utterances, hence, are used when the speaker wants to do face threatening act, but does not want to accept direct responsibility for doing it since the possible interpretations for an off record utterance are not only one clear communicative intention, it is up to the addressee to interpret it. Therefore, off-record utterances are basically indirect that require the addressee to make inference to get what was intended. Based on this basic and essential feature, off record utterances are mainly general (containing less information) or different from what one means (p. 211).

\subsection{Request}

The study of requests as an important element in linguistic studies of speech acts and psychology is prevalent in literature dealing with politeness. Besides the studies carried out by linguists within the field of speech act theory, there are a lot of studies on children's acquisition of pragmatic competence with their core focus on requests and other related materials on requests in English. Other types of research on requests refer to cross-

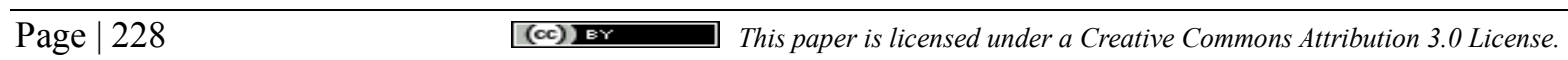


International Journal of Applied Linguistics \& English Literature

ISSN 2200-3592 (Print), ISSN 2200-3452 (Online)

Vol. 1 No. 5; September 2012 [Special Issue on General Linguistics]

cultural work on requests, including a project reported in Blum-Kulka and Olshtain (1984), focusing on the way of using requests and apologies in Hebrew, Danish, German, Canadian and French. The same cross-cultural studies carried out by Haverkate (1979) and Walters (1979) investigated requests in Spanish; and some other investigations comparing requests in English with those in Greek (Drossou 1985).

\subsection{Statement of the problem}

Brown and Levinson (1978) strongly believe that there exists some universals in politeness usage and most of languages follow the certain strategies to display honor and respect. Taking for granted this statement, the present study attempts to know whether the same universality exists among the students who learn English as their foreign language in upper- and advanced levels or not. The present study tries to investigate the similarities or possible differences among Persian learners of English and Turkish learners of English in deploying requests.

\subsection{Research Questions}

The study will investigate to find an answer to the following research questions:

1. Are the politeness strategies used by Persian EFL learners and Turkish EFL learners in making requests the same?

2. Is there any significant difference between students in each group according to their awareness in making requests?

The purpose of the study is to answer the research questions referred to before and to measure the degree of Iranian and Turkish students' awareness in making requests compared with the native speakers in using politeness strategies. This aim will be achieved through:

1. Analyzing the strategies of the Persian Learners of English (PLE ) in making requests,

2. Analyzing the strategies of the Turkish Learners of English (TLE ) in making requests,

3. Comparing both groups with each other and with native speakers' realization of the same requests.

\subsection{Hypotheses}

Based on the above mentioned research questions, five null hypotheses were formed as the following :

\subsubsection{Hypothesis 1}

There is no significant difference between the scores of students in using politeness strategies according to their majoring universities

\subsubsection{Hypothesis 2}

There is no significant difference between the scores of the first year students in using politeness strategies according to their majoring countries.

\subsubsection{Hypothesis 3}

There is no significant difference between the scores of the second year students in using politeness strategies according to their majoring universities.

\subsubsection{Hypothesis 4}

There is no significant difference between the scores of the third year students in using politeness strategies according to their majoring universities.

\subsubsection{Hypothesis 5}

There is no significant difference between the scores of the fourth year students in using politeness strategies according to their majoring universities.

\section{Method}

\subsection{Setting}

In this research setting refers to two different Universities in Turkey and Iran: Gazi University in Turkey and Tabriz Azad University In Iran. In both institutions, four different grade levels of the English learners study English Language Teaching.. These four grade levels in both universities include:

1) $1^{\text {st }}$ grade ELT students

2) $2^{\text {nd }}$ grade ELT students 
International Journal of Applied Linguistics \& English Literature

ISSN 2200-3592 (Print), ISSN 2200-3452 (Online)

Vol. 1 No. 5; September 2012 [Special Issue on General Linguistics]

3) $3^{\text {rd }}$ grade ELT students

4) $4^{\text {th }}$ grade ELT students

Tabriz Azad University, one of the famous universities in Iran, is situated in the province of East Azarbayjan in Iran and it includes degree programs in various fields of humanities and sciences. Gazi University one of the largest and oldest universities in Turkey, is located in Ankara, the capital city of Turkey. It also offers degree programs in various fields of humanities and sciences.

\subsection{Participants}

All of the subjects involved in this research were chosen among from teachers of English and students of ELT programs. The subjects in this research are three groups:

a) Native speakers of English

b) Turkish ELT students in Turkey

c) Iranian ELT students in Iran.

\subsubsection{Native speakers}

The native speakers of English in this study included 15 people who teach English in various Turkish universities. 20 native speakers were aimed at initially, but it was difficult to realize this number; therefore 15 English - speaking teachers of English were given the questionnaire. They acted as judges to provide us with the set of the correct answers of the test so that we could evaluate Turkish and Iranian students' proficiencies in politeness situations, in particular, in requests in various discoursed scripts.

All of these 15 subjects were presented a questionnaire including 10 questions based on different situations. For each situation, 4 different alternatives were suggested and the role of the native speakers was to suggest which one could be the most or the least appropriate option in each situation. Their responses were considered as the main reference to evaluate the ELT students' responses to the same questionnaires.

\subsubsection{Turkish and Iranian Students}

To obtain reliable data in our study, it was thought that four different educational groups were to be given the same questionnaire. Each grade level group consisted of a 56 students. The number of the students who answered the questionnaire in some groups exceeded 56. To homogenize all groups the minimum number available was decided to be the base reference, which became 56 . They were asked to choose the most and the least appropriate responses in 10 different scripts .Thus, 224 Turkish students in four different grade levels and the same number of Iranian students participated directly in this phase of the research.

\subsection{Instrument}

The research based mainly on a questionnaire adapted from Olshtain and Blum-Kulka (1985), which was used by Irman (1996). This questionnaire included 10 questions based on ten different social scripts each emphasizing a particular request. All three groups in our research were asked to mark only two alternatives provided for each question, one as "the most polite" and the other as "the least polite".

\subsection{Procedure}

In April 2005, permission for conducting the questionnaire was requested from both Tabriz Azad University and Gazi University to introduce the questionnaires to the students in four different grade levels and to collect the data from them. The questionnaires were given to the instructors of each class and asked to give a short explanation about the nature of the research and to encourage students to read the questions carefully and provide their reasonable answers for the options put forward in alternatives. The data collection procedure lasted for a week and for some grade levels, more than 75 questionnaires were completed. Because the minimum number for questionnaire returns was 56,56 was decided to be base number. Therefore, in each university the questionnaires of 224 students were taken into consideration.

The analysis procedure consists of different steps. First, the native speaker's responses were calculated. It followed a very simple procedure. By this I mean that first all of the responses for each situation, for example, situation one counted. In each situation the respondents should label alternative as the most polite and one as the least polite option. Therefore the similar and possibly different responses for situation one counted. For example, for situation one, 5 out of 15 respondents the native speakers-Labeled item ' $a$ ' as the most appropriate one and 10 of them labeled item ' $\mathrm{d}$ ' as the most appropriate choice. In that case, item ' $\mathrm{d}$ ' selected as the true response 


\section{International Journal of Applied Linguistics \& English Literature}

ISSN 2200-3592 (Print), ISSN 2200-3452 (Online)

Vol. 1 No. 5; September 2012 [Special Issue on General Linguistics]

because the majority of the native speakers believed in that one. The same procedure used for the least appropriate responses - as well. It was thought that if one item receives the equal answers or the difference would be just one - I mean 7 for item ' $a$ ' and 6 for item ' $b$ ', say, in that case both of them should be considered as the appropriate ones. The percentage of each items responses had to be calculated just to make it clear and illustrate it in a table. When this phase finished, then based on the native speakers preferences and their recognition, the Turkish and Iranian students' responses could be counted. The procedure based on marking each situation individually and each situation valued four scores two for the true the most appropriate one and two for the least appropriate one. Then, each questionnaire could be scored ranged from zero to forty (10 situations and four score for each one). This procedure could be applied for all the four student groups participated in the research in both countries. The results of this evaluation could be realized and interpreted through the referred computerized program known as $\underline{\text { SPSS }}$. The results and the evaluation of the scores will be appeared in the next section in detail.

\section{Results}

This section presents the distribution of "L"(the least polite ) and "M" ( the most polite) responses for the options by the native participants, native participant's final and correct responses to the presented situations, the number of participants means and T-scores of the results of the compared groups of subjects. Table 1 gives the distribution of "L" and "M" responses for the options by 15 native speakers . Tables 2 shows the correct answers of the test according to the responses of the native speakers. In situations 1, 8 and 10 , two correct answers are identified for the option "L" because two equal groups of native speakers or two equal groups with one difference chose two options as "L".

Table 1. The Distribution of (Situations )"L" and "M" Responses for the Options

\begin{tabular}{llllccccccc}
\hline Situation(S) & N & L & a & \multicolumn{3}{c}{ B } & \multicolumn{2}{c}{ c } & D & L \\
& 15 & L & M & L & M & L & M & L & M \\
\hline S1 & N & 6 & 0 & 5 & 0 & 0 & 9 & 4 & 6 \\
S2 & N & 0 & 2 & 10 & 0 & 1 & 12 & 4 & 1 \\
S3 & N & 9 & 0 & 1 & 13 & 3 & 2 & 2 & 0 \\
S4 & N & 8 & 0 & 0 & 2 & 3 & 10 & 4 & 3 \\
S5 & N & 0 & 13 & 10 & 1 & 2 & 0 & 3 & 1 \\
S6 & N & 5 & 2 & 6 & 0 & 2 & 3 & 2 & 10 \\
S7 & N & 5 & 3 & 7 & 0 & 2 & 8 & 1 & 4 \\
S8 & N & 5 & 1 & 5 & 1 & 2 & 10 & 3 & 3 \\
S9 & N & 3 & 1 & 4 & 2 & 2 & 12 & 6 & 0 \\
S10 & N & 5 & 1 & 5 & 1 & 4 & 2 & 1 & 11 \\
\hline
\end{tabular}

Table 2. Native Participant's Final and Correct responses to the Presented Situations

\begin{tabular}{ccc}
\hline & Correct "L" Responses & Correct "M" Responses \\
\hline Situation 1 & $\mathrm{a} \cdot \mathrm{b}$ & $\mathrm{C}$ \\
Situation 2 & $\mathrm{B}$ & $\mathrm{C}$ \\
Situation 3 & $\mathrm{A}$ & $\mathrm{B}$ \\
Situation 4 & $\mathrm{~A}$ & $\mathrm{C}$ \\
Situation 5 & $\mathrm{~B}$ & $\mathrm{~A}$ \\
Situation 6 & $\mathrm{~B}$ & $\mathrm{D}$ \\
Situation 7 & $\mathrm{~B}$ & $\mathrm{C}$ \\
Situation 8 & $\mathrm{a} \cdot \mathrm{b}$ & $\mathrm{C}$ \\
Situation 9 & $\mathrm{D}$ & $\mathrm{C}$ \\
Situation 10 & $\mathrm{a} \cdot \mathrm{b}$ & $\mathrm{D}$ \\
\hline
\end{tabular}




\section{International Journal of Applied Linguistics \& English Literature}

ISSN 2200-3592 (Print), ISSN 2200-3452 (Online)

Vol. 1 No. 5; September 2012 [Special Issue on General Linguistics]

The figures 1, 2 demonstrate that the total mean for English students in Gazi university is more and it has less distribution compared to Tabriz Azad university and also it follows a normal distribution that approximately 95\% of the scores fall in 1.96 section, but the scores in the Tabriz Azad university are negatively skewed. In Gazi University most of the scores ranges from 65-75 while in Tabriz Azad university this range is different and varies from 55-65.

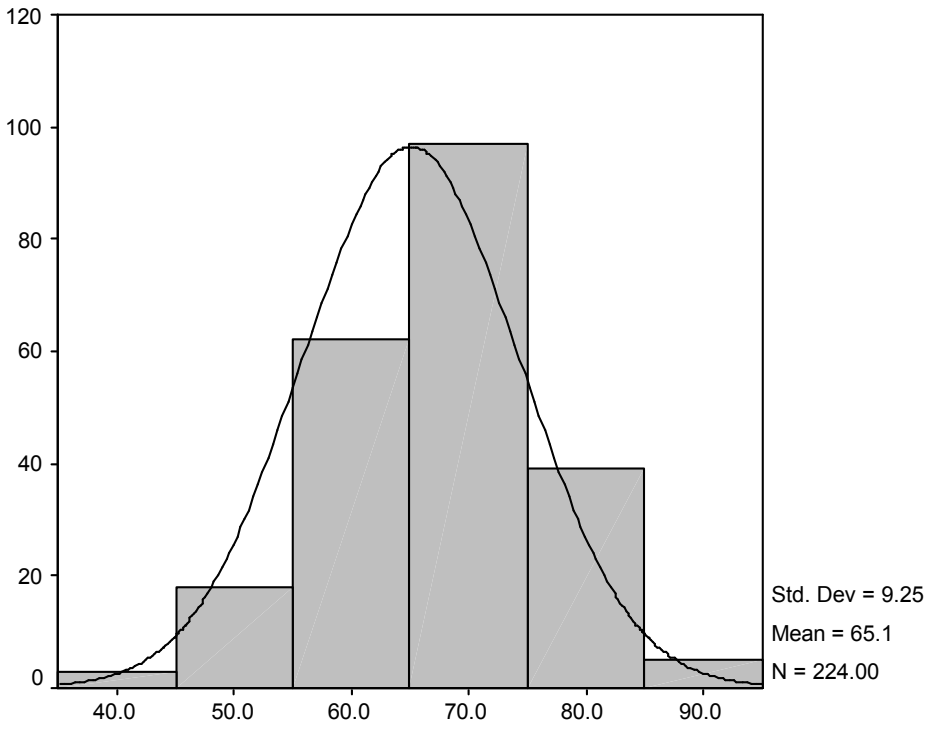

Figure 1. Total Score Distribution- Bell-Shaped Histogram of English Students in Gazi University

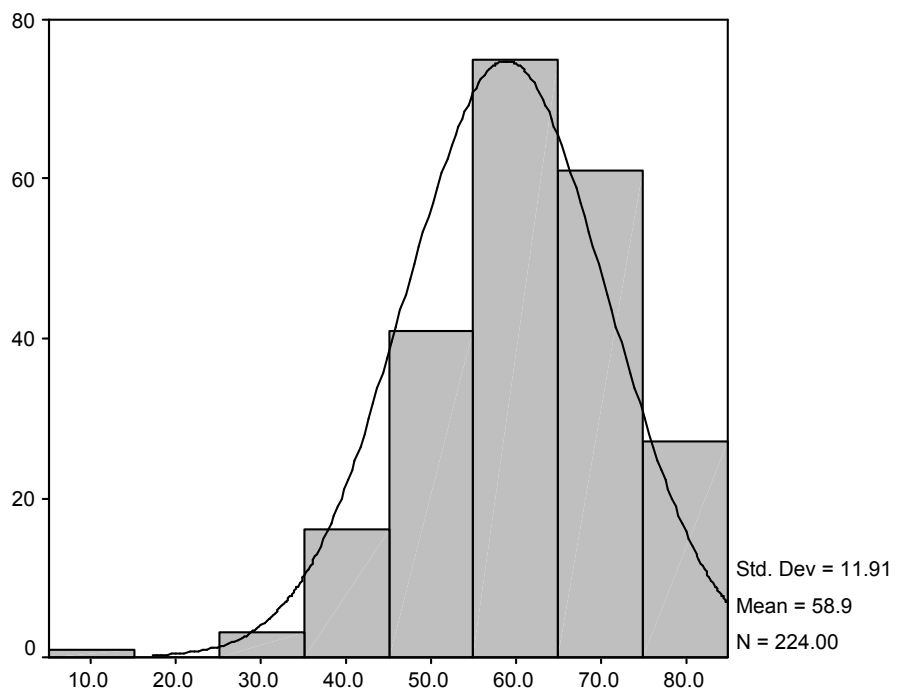

Figure 2. Total Score Distribution- Bell-Shaped Histogram of English Students in Tabriz Azad University.

\subsubsection{Interpretation of the data}

In this section, first the research data is going to be dealt with and then based on the data the related hypotheses would be proved or rejected.

\subsubsection{Evaluation specification}

One sample Kolmogorov- Smirnov test (Table 3) shows whether the data is normal to assign a statistical evaluation in order to prove or reject the hypotheses. 
International Journal of Applied Linguistics \& English Literature

ISSN 2200-3592 (Print), ISSN 2200-3452 (Online)

Vol. 1 No. 5; September 2012 [Special Issue on General Linguistics]

Table 3. One - sample Kolmogorov - Smirnov Test

\begin{tabular}{ll|c}
\hline & & $\begin{array}{c}\text { The score of Turkish \& Iranian university } \\
\text { students in different classes }\end{array}$ \\
\hline Number & & 448 \\
Normal Parameters & Mean & 61.99 \\
& Std. Deviation & 11.09 \\
Most Extreme & Absolute & .123 \\
Differences & Positive & .076 \\
Kolmogrov- Smirnov Z & Negative & -.123 \\
Asymp. Sig. (2-tailed) & & 2.606 \\
\hline
\end{tabular}

a. Test distribution is Normal.

b. Calculated from data.

The table 3. shows that the related data for the variable in this research, including the data obtained from Gazi and Tabriz Azad university, students studying in four different years, follow a normal distribution .Hence, Parametric evaluation is used.

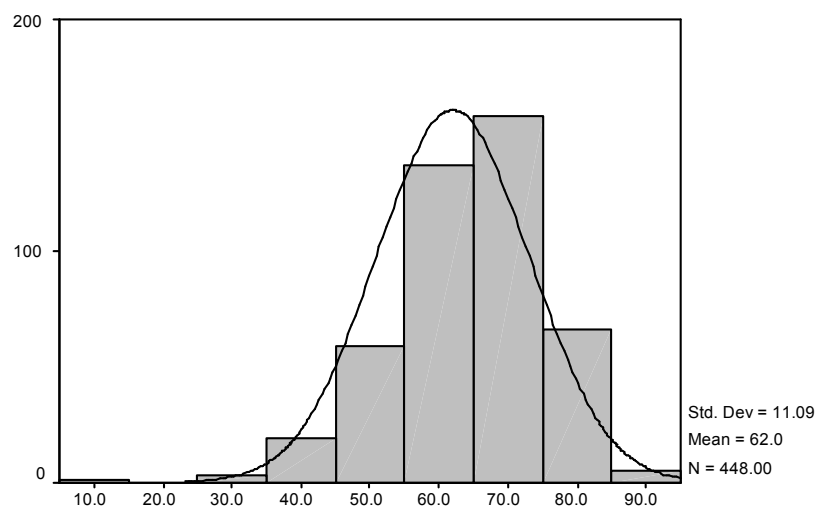

Figure 3. The scores of Tabriz Azad University and Gazi University students in four different levels

This figure shows the distribution of Tabriz Azad university and Gazi University students scores.

\subsubsection{Hypotheses}

Hypothesis 1:

There is no significant difference between the scores of students in using politeness strategies according to their majoring universities.

Table 4. Descriptive Statistical Scores of the Students in Tabriz Azad and Gazi Universities

\begin{tabular}{ccccc}
\hline University & $\mathrm{N}$ & Mean & Std.Deviation & Std.Error Mean \\
\hline Gazi & 224 & 65.07 & 9.25 & .62 \\
Tabriz Azad & 224 & 58.91 & 11.91 & .80 \\
\hline
\end{tabular}

As the table shows the mean of the scores of students at Gazi university is $(M=65.07, S D=9.25)$ whereas, for Tabriz students is $(\mathrm{M}=58.91, \mathrm{SD}=11.91)$. In order to find out whether there is a significant difference between the mean scores of the students in Tabriz Azad University and Gazi University, an independent sample T-test was run. (Table 5)

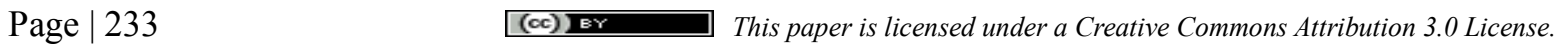


International Journal of Applied Linguistics \& English Literature

ISSN 2200-3592 (Print), ISSN 2200-3452 (Online)

Vol. 1 No. 5; September 2012 [Special Issue on General Linguistics]

Table 5. Independent T scores for Tabriz Azad University and Gazi University students

\begin{tabular}{|c|c|c|c|c|c|c|c|c|c|c|}
\hline & & $\begin{array}{c}\text { Lev } \\
\text { Tes } \\
\text { Equa } \\
\text { Vari }\end{array}$ & $\begin{array}{l}\text { ne's } \\
\text { for } \\
\text { ty of } \\
\text { cces }\end{array}$ & \multicolumn{7}{|c|}{ t-test for Equality of Means } \\
\hline & & \multirow[t]{2}{*}{$\mathrm{F}$} & \multirow[t]{2}{*}{ Sig. } & \multirow[t]{2}{*}{$\mathrm{t}$} & \multirow[t]{2}{*}{ df } & \multirow[t]{2}{*}{$\begin{array}{c}\text { Sig. } \\
\text { (2-tailed) }\end{array}$} & \multirow[t]{2}{*}{$\begin{array}{c}\text { Mean } \\
\text { Difference }\end{array}$} & \multirow[t]{2}{*}{$\begin{array}{l}\text { Std. Error } \\
\text { Difference }\end{array}$} & \multicolumn{2}{|c|}{$\begin{array}{c}95 \% \text { Confidence } \\
\text { Interval of the } \\
\text { Difference }\end{array}$} \\
\hline & & & & & & & & & Lower & Upper \\
\hline \multirow[t]{2}{*}{ Score } & $\begin{array}{l}\text { Equal } \\
\text { variances } \\
\text { assumed }\end{array}$ & 13.6 & .000 & 6.113 & 446 & .000 & 6.16 & 1.01 & 4.18 & 8.14 \\
\hline & $\begin{array}{l}\text { Equal } \\
\text { variances } \\
\text { not } \\
\text { assumed }\end{array}$ & & & 6.113 & 42.02 & .000 & 6.16 & 1.01 & 4.18 & 8.14 \\
\hline
\end{tabular}

Based on the table the variances of the two groups are equal .So, the results indicate a significant difference, $\mathrm{t}(6.113)=446, \mathrm{t}(6.113)=420.2, \mathrm{p}=0.000$ between the mean scores of the students of two universities .

The tables show that with $95 \%$ degree of confidence $(\mathrm{P}<0.05)$ there exists a significant statistical difference between Gazi students and Tabriz Azad university students. The tables show that Gazi students act better than Tabriz Azad university students in using politeness strategies. Therefore, the first hypothesis is rejected.

Hypothesis 2:

There is no significant difference between the scores of the first year students in terms of being aware of politeness strategies according to their countries.

Table 6. Descriptive Statistical Scores of the first Year Students in Tabriz Azad University and Gazi Universities

\begin{tabular}{lcccc}
\hline \multicolumn{1}{c}{ University } & $\mathrm{N}$ & Mean & Std.Deviation & Std.Error Mean \\
\hline Gazi & 56 & 63.48 & 8.58 & 1.15 \\
Tabriz Azad & 56 & 61.07 & 11.97 & 1.60 \\
\hline
\end{tabular}

Table 7. Independent T Scores for the Second Year Students in Tabriz Azad university and Gazi University

\begin{tabular}{|c|c|c|c|c|c|c|c|c|c|c|}
\hline & & $\begin{array}{l}\text { Levene } \\
\text { for } \mathrm{Eq} \\
\text { of } \mathrm{Var}\end{array}$ & $\begin{array}{l}\text { Test } \\
\text { ality } \\
\text { ances }\end{array}$ & \multicolumn{7}{|c|}{ t-test for Equality of Means } \\
\hline & & \multirow[t]{2}{*}{$\mathrm{F}$} & \multirow[t]{2}{*}{ Sig. } & \multirow[t]{2}{*}{$\mathrm{t}$} & \multirow[t]{2}{*}{ df } & \multirow[t]{2}{*}{$\begin{array}{c}\text { Sig. } \\
\text { (2-tailed) }\end{array}$} & \multirow[t]{2}{*}{$\begin{array}{c}\text { Mean } \\
\text { Difference }\end{array}$} & \multirow[t]{2}{*}{$\begin{array}{l}\text { Std. Error } \\
\text { Difference }\end{array}$} & \multicolumn{2}{|c|}{$\begin{array}{l}95 \% \text { Confidence } \\
\text { Interval of the } \\
\text { Difference }\end{array}$} \\
\hline & & & & & & & & & Lower & Upper \\
\hline \multirow[t]{2}{*}{ Score } & $\begin{array}{l}\text { Equal } \\
\text { variances } \\
\text { assumed }\end{array}$ & 6.919 & .010 & 1.225 & 110 & .233 & 2.41 & 1.97 & 1.49 & 6.31 \\
\hline & $\begin{array}{l}\text { Equal } \\
\text { variances } \\
\text { not } \\
\text { assumed }\end{array}$ & & & 1.225 & 99.677 & .224 & 2.41 & 1.97 & 1.49 & 6.32 \\
\hline
\end{tabular}




\section{International Journal of Applied Linguistics \& English Literature}

ISSN 2200-3592 (Print), ISSN 2200-3452 (Online)

Vol. 1 No. 5; September 2012 [Special Issue on General Linguistics]

Tables 6 and 7 indicate the comparison of the means of two groups. Group 1 displays Turkish students and Group 2 shows Iranian students. The mean obtained for the first year of Gazi students is $(\mathrm{M}=63.48, \mathrm{SD}=8.58)$ while it is $(\mathrm{M}=61.07, \mathrm{SD}=11.97)$ for Tabriz Azad university students. The mean difference between the two groups is $2.41(\mathrm{p}>0.05)$ and with $95 \%$ degree of confidence the tables show that there is not a meaningful difference between the two groups according to their majoring universities. So the hypothesis is accepted.

Hypothesis 3:

There is no significant difference between the scores of the second year students in being aware of politeness strategies according to their universities.

Table 8. Descriptive Statistical Scores of the Second Year Students in Tabriz Azad university and Gazi University

\begin{tabular}{ccccc}
\hline University & $\mathrm{N}$ & Mean & Std.Deviation & Std.Error Mean \\
Gazi & 56 & 64.29 & 8.81 & 1.18 \\
Tabriz Azad & 56 & 60.63 & 12.47 & 1.67 \\
\hline
\end{tabular}

Table 9. Independent T Scores for the Second Year Students in Tabriz Azad university and Gazi University

\begin{tabular}{|c|c|c|c|c|c|c|c|c|c|c|}
\hline & & $\begin{array}{l}\text { Leven } \\
\text { for } \mathrm{E} \\
\text { of } \mathrm{Va}\end{array}$ & $\begin{array}{l}\text { Test } \\
\text { ality } \\
\text { ances }\end{array}$ & \multicolumn{7}{|c|}{ t-test for Equality of Means } \\
\hline & & \multirow[t]{2}{*}{$\mathrm{F}$} & \multirow[t]{2}{*}{ Sig. } & \multirow[t]{2}{*}{$\mathrm{t}$} & \multirow[t]{2}{*}{ df } & \multirow[t]{2}{*}{$\begin{array}{c}\text { Sig. } \\
\text { (2-tailed) }\end{array}$} & \multirow[t]{2}{*}{$\begin{array}{c}\text { Mean } \\
\text { Difference }\end{array}$} & \multirow[t]{2}{*}{$\begin{array}{l}\text { Std. Error } \\
\text { Difference }\end{array}$} & \multicolumn{2}{|c|}{$\begin{array}{l}95 \% \text { Confidence } \\
\text { Interval of the } \\
\text { Difference }\end{array}$} \\
\hline & & & & & & & & & Lower & Upper \\
\hline \multirow[t]{2}{*}{ Score } & $\begin{array}{l}\text { Equal } \\
\text { variances } \\
\text { assumed }\end{array}$ & 1.934 & .167 & 1.794 & 110 & 0.76 & 3.66 & 2.04 & .38 & 7.70 \\
\hline & $\begin{array}{l}\text { Equal } \\
\text { variances } \\
\text { not } \\
\text { assumed }\end{array}$ & & & 1.794 & 98.968 & 0.76 & 3.66 & 2.04 & .39 & 7.71 \\
\hline
\end{tabular}

The means of Turkish students in second year of majoring English at Gazi university is $(\mathrm{M}=64.29, \mathrm{SD}=8.81)$ and for Iranian students at Tabriz Azad University the mean is $(\mathrm{M}=60.63, \mathrm{SD}=12.47)$ and the mean difference between these two groups is $3.66(\mathrm{p}>0.50)$.

The result with $95 \%$ degree of confidence displays there is not a significant difference between the second year English student's scores of Gazi and Tabriz Azad universities. In other words, there is not a difference between second year English students at Gazi and Tabriz universities .So, the hypothesis is accepted.

Hypothesis 4:

There is no significant difference between the scores of the third year students in using politeness strategies according to their majoring universities.

Table 10. Descriptive Statistical Scores of the third Year Students in Tabriz Azad University and Gazi University

\begin{tabular}{lllcc}
\hline \multicolumn{1}{c}{ University } & $\mathrm{N}$ & Mean & Std.Deviation & Std.Error Mean \\
\hline Gazi & 56 & 66.34 & 10.72 & 1.43 \\
Tabriz Azad & 56 & 56.43 & 11.67 & 1.56 \\
\hline
\end{tabular}

As the Table 10 shows the means of the third year English students at Gazi university is) $\mathrm{M}=66.34, \mathrm{SD}=$ $10.72)$ and for Tabriz students in the same level is $(\mathrm{M}=56.43, \mathrm{SD}=11.67)$. 


\section{International Journal of Applied Linguistics \& English Literature}

ISSN 2200-3592 (Print), ISSN 2200-3452 (Online)

Vol. 1 No. 5; September 2012 [Special Issue on General Linguistics]

The result with $95 \%$ degrees of confidence reveals that there is a significant difference between the third year English students in Gazi and Tabriz Azad universities and the mean is bigger for Turkish students than Iranian students so, The hypothesis is rejected.

In order to find out whether there is a significant difference between the mean scores of the third year students in Tabriz Azad University and Gazi University, an independent sample T-test was run (Table 11).

Table 11. Independent T scores for the Third Year Students in Tabriz Azad University and Gazi University

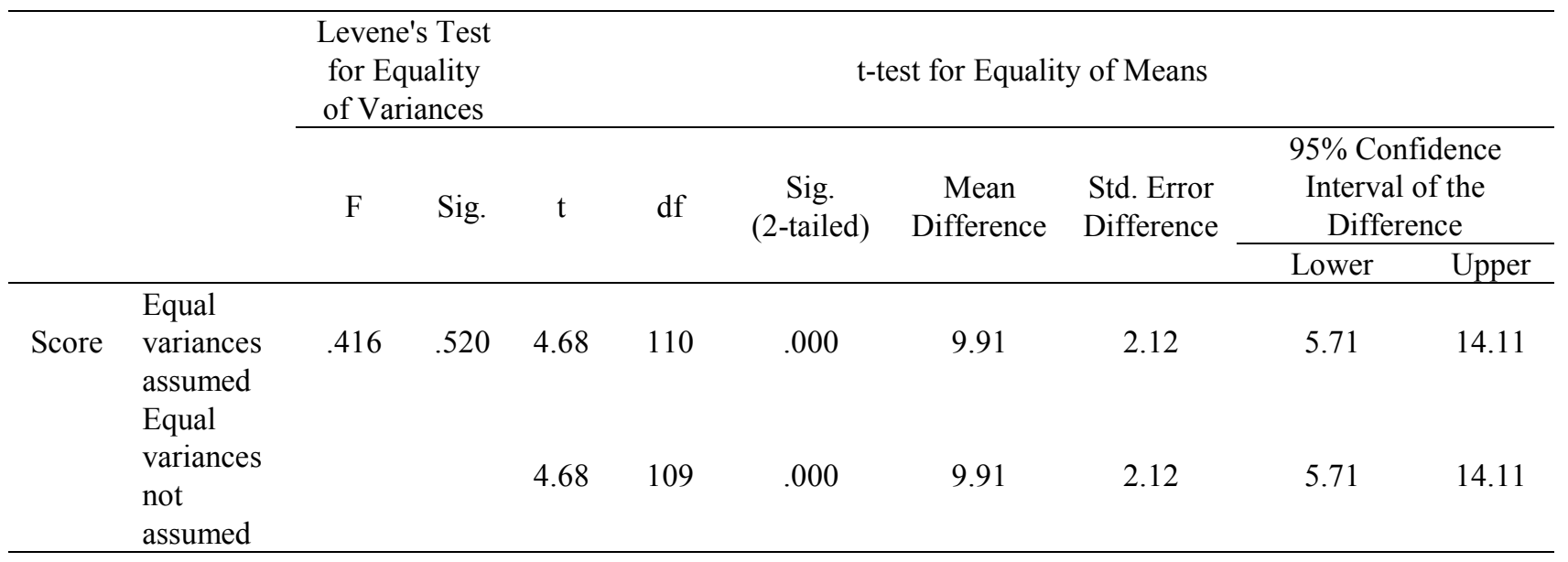

Based on the table the variances of the two groups are equal, therefore, the equal variances assumed and the results indicate a significant difference, $\mathrm{t}(110)=4.68, \mathrm{P}=.000$, between the mean scores of the students of two universities . Thus, the first null hypothesis is rejected.

Hypothesis 5:

There is no significant difference between the scores of the fourth year students in terms of being aware of politeness strategies according to their universities.

Table 12. Descriptive statistical scores of the fourth year students in Tabriz Azad University and Gazi University

\begin{tabular}{llccc}
\hline \multicolumn{1}{c}{ University } & $\mathrm{N}$ & Mean & Std.Deviation & Std.Error Mean \\
\hline Gazi & 56 & 66.16 & 8.63 & 1.15 \\
Tabriz Azad & 56 & 57.50 & 11.16 & 1.49
\end{tabular}

Table 13. Independent T Scores for the Fourth Year Students in Tabriz Azad University and Gazi University

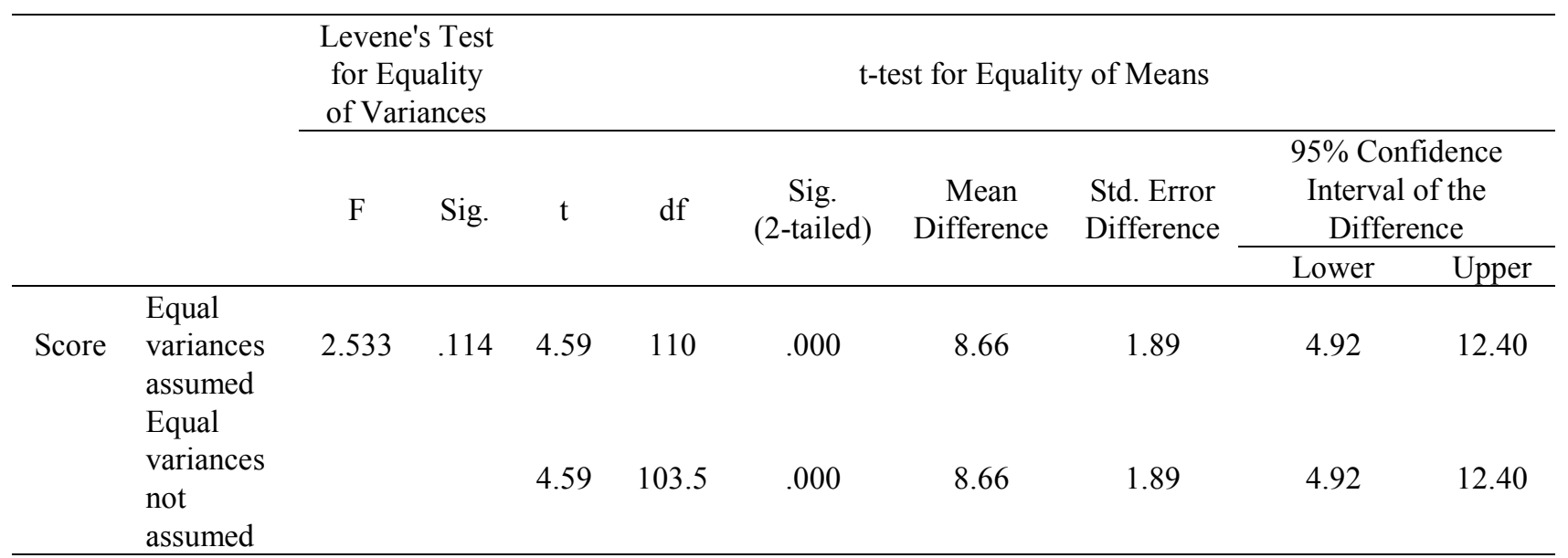

${ }^{*} \mathrm{p}<0.05$

Page $\mid 236$ 
International Journal of Applied Linguistics \& English Literature

ISSN 2200-3592 (Print), ISSN 2200-3452 (Online)

Vol. 1 No. 5; September 2012 [Special Issue on General Linguistics]

Tables 12 and 13 show the fourth year English students' scores in both countries. Group 1 displays Gazi students' scores and group 2 shows the scorers of Tabriz Azad University students . The means of Turkish students $(\mathrm{M}=66.16, \mathrm{SD}=8.63)$ and for Iranian students this mean is $(\mathrm{M}=57.50, \mathrm{SD}=11.16)$ and the mean difference between these two groups is 8.66 and $\mathrm{p}<0.05$.

The result with $95 \%$ degree of confidence shows that a there is a significant difference between the means of the fourth year students' scores at Gazi and Tabriz universities The scores obtained by Gazi students are better than Tabriz students' scores. Based on the result, there is a significant difference between these two groups and the hypothesis is rejected.

\section{Discussion}

The research is completely based on the assumptions put forward by Brown \& Levinson (1987) who believe there exists common rules in using politeness strategies among different cultures. The present research has tried to investigate the feasibility of such an assumption through a cross-cultural analysis of the students who learn a second language in the relatively same levels in two different countries. Apparently, the issue of politeness covers a wide range of topics which investigating all of them seem impossible and improper. Hence, the present research has tried to probe just an element of a very broad domain - requests. Realizing the importance and necessity of limiting the realm, the research has adopted the measurement tool used by Kulkand Olshtain (1985) collecting information from native speakers through devising a questionnaire including various social scripts which the natives should mark the most appropriate and the least appropriate responses, a model was achieved and the mean of all responses calculated for each individual item. The most appropriate and the least appropriate utterances became clear and the next step was to apply the findings to our own cross-cultural investigation. The exact purpose of the study has been to investigate 1) any possible differences between the foreign language learners in two relatively different cultures - Iran and Turkey.

To provide a valid and reliable answer to these research questions, four groups of learners in each country were selected. These four groups were students who study English in the first to the fourth year of majoring English in their English faculties in their home countries. Five hypotheses according to the research questions appeared.

\section{Conclusion and Implications}

The results of the research shows that some universal correlations exist in using politeness strategies The analysis of the results in each two groups revealed the fact that there was not any significant gap between the four-group students in each university. The results show that there is a consistency in each group students' results. The cross-cultural analysis of the Gazi and Tabriz Azad universities, on the other hand, revealed that in some cases there is a significant difference between these two compared groups and the difference is statistically significant. Therefore, it can be suggested that a same request in two different languages could be observed differently and the difference does not have any relation to the language, rather to the background knowledge and the schema theory. The results show that each group perceives the politeness according to their own cultural preferences.

The implication based on this assumption can claim that politeness is a cultural and social concept and should not be mixed merely to linguistic knowledge .The finding have remarkable implications for language teaching .knowing that appropriate use of politeness can prevent serious misunderstandings between the speakers، language teachers should be aware of the necessity of sociolinguistic information in language instruction and they should be concerned with how to teach such pieces of pragmatic information.

Those who are interested in this field can investigate the issue of politeness and particularly requests through recording subjects responses authentically. By this I mean that, they can mantle cameras in some classes and through camera observation record the subjects responses to some stimulations that are planned through some role plays. Through the role plays and the way subjects react to those pre-decided situations, the possible different forms of responses can be recorded and later analyzed through the strategies suggested by Brown and Levinson (1987).

\section{References}

Austin, J.L. (1962). How To Do Things With Words. Oxford: Clarendon Press.

Brown, P. and Levinson, S. (1978). Universals in language usage: Politeness phenomena. In E. Goody (ed.) Questions and politeness: Strategies in Social Interaction. Cambridge: Cambridge University Press, pp. 56-311. 
International Journal of Applied Linguistics \& English Literature

ISSN 2200-3592 (Print), ISSN 2200-3452 (Online)

Vol. 1 No. 5; September 2012 [Special Issue on General Linguistics]

Blum-Kulka, S. and Olshtain, E. (1985). Requests and apologies: a cross- cultural study of speech act realization patterns (CCSARP). Applied linguistic 5(3): 146-212.

Drossou, M. (1985). Requests in English and in Greek. MA dissertation, University of York.

Fukada, A. and Asto, N. (2004). Universal politeness theory: application to the use of Japanese honorifics.

Journal of Pragmatics 36, 1991-2002.

Goffman, E.(1967) Interaction ritual : essays on face to face behavior. Garden City, New York

Haverkate, H. (1979). Impositive sentence in Spanish: theory and description in pragmatics. Amsterdam.

İrman, İ. (1996). An Evaluation of the Communicative Success of Turkish EFL Learners in Utilizing Politeness

Strategies in Requests. Ingilizce' yi Yabancı Dil Olarak Öğrenen Türk Öğrenecilerin Ingilizce' deki Ricalardaki

kibarlık Stratejilerini Kullanmalarındaki Iletişimsel Başarılarının Değerlendirilmesi. Unpublished Master's

Thesis. Eskisehir, Anadolu University.

Lakoff, R. (2001). The logic of politeness: or minding your p's and q's. Proceedings of the Ninth Regional

Meeting of the Chicago Linguistic Society, pp. 292-305.

Leech, G. N. (1983). Principles of Pragmatics. London.

Nevala, M. (2004). Accessing politeness exes: forms of address and terms of reference in early English correspondence. Journal of Pragmatics, 36 (2004) 2125-2160.

Searle, J.R. (1965). What is a speech act? In: Black, M. 9ed.), Philosophy in America. Routledge, London.

Searle, J.R. (1979). Expression and Meaning. Cambridge: Cambridge University Press.

Searle, J. R. (1969). Speech Acts. Cambridge: Cambridge University Press.

Thomas, J.(1995).The language of power: towards a dynamic pragmatics, Journal of pragmatics.9(6): 199-216

Walters, J. (1979). Strategies for requesting in Spanish and English: Structural similarities and pragmatic

differences. Language Learning 29(2): 277-94.

\section{APPENDIX 1}

The Original Questionnaire Adapted From Olshtain and Blum- Kulka, Used by Irman (1996). A QUESTIONNAIRE ON POLITENESS STATEGIES USED IN REQUESTS
A. Age:
B. Sex:
C. Nationality:

Each of the following situations describes an event which might easily take place in reality. The situation is followed by four different sentences. Please rate each sentence on a scale as being:

$1=$ appropriate

$2=$ more or less appropriate

$3=$ not appropriate

(You may use 1, 2, or 3 for more than one option.)

SITUATION 1

You are a bank officer and you realize that an old man is not in line. You ask him to get in line.

( ) a. Please get in line, sir.

( ) b. why don't you get in line, sir?

( ) c. Could you please get in line, sir.

( ) d. Sir, we ask that all our customers use the line.

\section{SITUATION 2}

You are trying to study. Your roommate who is about your age is playing his/her music tapes very loudly. You ask him/her to turn it down.

( ) a. Turn it down, please.

( ) b. We're gonna go deaf.

( ) c. Can you turn the music down?

( ) d. Do me a favor and turn it down.

SITUATION 3

You are attending the first lesson of a new course. The classroom is very hot. The professor is standing near the window. You ask him to open it. 
International Journal of Applied Linguistics \& English Literature

ISSN 2200-3592 (Print), ISSN 2200-3452 (Online)

Vol. 1 No. 5; September 2012 [Special Issue on General Linguistics]

( ) a. Do me a favor and open the window, sir.

( ) b. Could you please open the window sir?

( ) c. Open the window, please.

( ) d. Isn't it hot in here, sir?

\section{SITUATION 4}

You are in a pastry shop. You ask the shop assistant who is younger than you to give you the big chocolate cake in the front window.

( ) a. Any chance of giving me this one?

( ) b. I prefer chocolate cake.

( ) c. Excuse me, could you give me this one?

( ) d. Give me this one, please.

\section{SITUATION 5}

You are in the dean's office. You ask him to write a letter of recommendation which you need to be eligible for a scholarship.

( ) a. Excuse me, would it be possible for you to write a letter of recommendation for me?

( ) b. Why don't you write a letter of recommendation for me sir?

( ) c. I urgently need a letter of recommendation.

( ) d. Sir, write a letter of recommendation for me, please.

\section{SITUATION 6}

When talking about literature with your friend who is about your age, you have discovered that s/he has a book you would like to have, but couldn't find in any stores. You ask him/her to lend it to you.

( $\quad$ ) a. Lend me that book, please.

( ) b. Why don't you lend it to me?

( ) c. I have been looking for this book for ages.

( ) d. Can you lend me that book?

\section{SITUATION 7}

You are a receptionist in a hotel. You ask a customer who is younger than you to leave the key before leaving the hotel

( ) a. Leave the key, please.

( ) b. Why don't you leave the key?

( ) c. We ask that all our guests leave their keys with us before leaving the hotel.

( ) d. Could you please leave key?

\section{SITUATION 8}

You are at home preparing to have your dinner. You realize that there isn't any bread at home. You call the doorman's son and want him to buy a loaf of bread.

( ) a. I need a loaf of bread

( ) b. Get me a loaf of bread, Please.

( ) c. Can you get me a loaf of bread?

( ) d. Do me a favor and get a loaf of bread.

\section{SITUATION 9}

Your are a student. A research assistant who is younger than you gives you a lift downtown. You ask him to drop you off somewhere near the post office.

( ) a. Why don't you drop me off somewhere near the post office?

( ) b. Drop me off somewhere near the post office, please.

( ) c. Could you drop me off somewhere near the post office?

( ) d. A-ha! Here is the post office.

SITUATION 10

You are in the canteen with your friend and you ask the man who is older than you to serve you two cups of coffee.

( ) a. Give us two cups of coffee, please.

( ) b. Why don't you give us two cups of coffee?

( ) c. Is the coffee fresh?

( ) d. Can you give us two cups of coffee? 
International Journal of Applied Linguistics \& English Literature

ISSN 2200-3592 (Print), ISSN 2200-3452 (Online)

Vol. 1 No. 5; September 2012 [Special Issue on General Linguistics]

\section{APPENDIX 2}

\section{The Modified Questionnaire Given to English Native Speakers inTurkey and Students of ELT \\ Departments in Gazi University and Tabriz Azad University}

\section{A Test on Politeness Strategies Used in Requests}

Each situation below describes an event which might easily take place in daily life. Each situation is followed by four different utterances. Please:

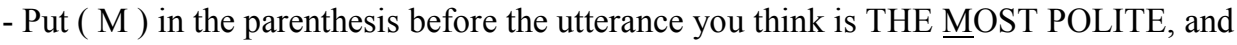

- Put ( L ) in the parenthesis before the utterance you think is THE LEAST POLITE.

\section{SITUATION 1}

You are a bank teller and you realize that an old man is not in line. You ask him to get in line.

( ) a. Please get in line, sir.

( ) b. why don't you get in line, sir?

( ) c. Could you please get in line, sir.

( ) d, Sir, we ask that all our customers use the line.

\section{SITUATION 2}

You are trying to study. Your roommate who is about your age is playing his/her music tapes very loudly. You ask him/her to turn it down.

( ) a. Turn it down, please.

( ) b. We're gonna go deaf.

( ) c. Can you turn the music down?

( ) d. Do me a favor and turn it down.

\section{SITUATION 3}

You are attending the first lesson of a new course. The classroom is very hot. The professor is standing near the window. You ask him to open it.

( ) a. Do me a favor and open the window, sir.

( ) b. Could you please open the window sir?

( ) c. Open the window, please.

( ) d. Isn't it hot in here, sir?

\section{SITUATION 4}

You are in a pastry shop. You ask the shop assistant who is younger than you to give you the big chocolate cake in the front window.

( ) a. Any chance of giving me this one?

( ) b. I prefer chocolate cake.

( ) c. Excuse me, could you give me this one?

( ) d. Give me this one, please.

\section{SITUATION 5}

You are in the dean's office. You ask him to write a letter of recommendation which you need to be eligible for a scholarship.

( ) a. Excuse me, would it be possible for you to write a letter of recommendation for me?

( ) b. Why don't you write a letter of recommendation for me sir?

( ) c. I urgently need a letter of recommendation.

( ) d. Sir, write a letter of recommendation for me, please. 
International Journal of Applied Linguistics \& English Literature

ISSN 2200-3592 (Print), ISSN 2200-3452 (Online)

Vol. 1 No. 5; September 2012 [Special Issue on General Linguistics]

\section{SITUATION 6}

When talking about literature with your friend who is about your age, you have discovered that $\mathrm{s} / \mathrm{he}$ has a book you would like to have, but couldn't find in any stores. You ask him/her to lend it to you.

( ) a. Lend me that book, please.

( ) b. Why don't you lend it to me?

( ) c. I have been looking for this book for ages.

( ) d. Can you lend me that book?

\section{SITUATION 7}

You are a receptionist in a hotel. You ask a customer who is younger than you to leave the key before leaving the hotel.

( ) a. Leave the key, please.

( ) b. Why don't you leave the key?

( ) c. We ask that all our guests leave their keys with us before leaving the hotel.

( ) d. Could you please leave key?

\section{SITUATION 8}

The person next to you has just finished reading a newspaper you are interested in. You request his to give it to you.

( ) a. would it be all right if I ask you to give me your newspaper?

( ) b. Can you give me your newspaper, please?

( ) c. why don't you give me your newspaper?

( ) d. Is it 11 right if I ask you to give me hour newspaper.

\section{SITUATION 9}

Your are a student. A research assistant who is younger than you gives you a lift downtown. You ask him to drop you off somewhere near the post office.

( ) a. Why don't you drop me off somewhere near the post office?

( ) b. Drop me off somewhere near the post office, please.

( ) c. Could you drop me off somewhere near the post office?

( ) d. A-ha! Here is the post office.

\section{SITUATION 10}

You are in the canteen with you friend and you ask the man who is older than you to serve you two cups of coffee.

( ) a. Give us two cups of coffee, please.

( ) b. Why don't you give us two cups of coffee?

( ) c. Is the coffee fresh?

( ) d. Can you give us two cups of coffee? 